\title{
Identification and characterization of pestiviruses isolated from individual fetal bovine serum samples originated in Rio Grande do Sul state, Brazil ${ }^{1}$
}

\author{
Ingryd Merchioratto ${ }^{2}$ (D), Francielle L. Monteiro ${ }^{3}$ (D), Carolina K. Traesel $^{5}$ (D), \\ Eduardo F. Flores ${ }^{4}$ (D), Rudi Weiblen ${ }^{4}$ (D) and Mário C.S. Brum ${ }^{5 *}$ (D)
}

\begin{abstract}
Merchioratto I., Monteiro F.L., Traesel C.K., Flores E.F., Weiblen R. \& Brum M.C.S. 2020. Identification and characterization of pestiviruses isolated from individual fetal bovine serum samples originated in Rio Grande do Sul state, Brazil. Pequisa Veterinária Brasileira 40(5):368-373. Laboratório de Virologia, Curso de Medicina Veterinária, Universidade Federal do Pampa, BR-472 Km 585, Cx. Postal 118, Uruguaiana, RS 97508-000, Brazil. E-mail: mariobrum@unipampa.edu.br

The identification of diversity of bovine pestiviruses circulating in the field is fundamental for continuous evaluation of diagnostic tests and vaccine composition. In this article we performed the genetic and antigenic characterization of twelve bovine pestiviruses isolated in the western region of Rio Grande do Sul, Brazil. The viruses were isolated from sera of bovine fetuses or from animals with clinical presentations suggestive of pestivirus infection. Genetic characterization by sequencing and phylogenetic analysis of the 5'UTR region of the viral genome allowed for the identification of bovine viral diarrhea virus (BVDV-1a, 4/12, 33.3\%), BVDV-1b $(6 / 12,50 \%)$ and BVDV-2 $(2 / 12,16.7 \%)$. The reactivity of the isolates with a panel of monoclonal antibodies raised against envelope proteins (Erns, E1 and E2) demonstrated a high antigenic variability among isolates. Thus, the active circulation of bovine pestivirus infection, with high genetic and antigenic variability, in cattle on the western border of RS was confirmed, demonstrating the importance of continuous characterization of the pestiviruses circulating in the cattle herds to keep the diagnostic and control measures up to date.
\end{abstract}

INDEX TERMS: Pestivirus, fetus, serum, bovine, Brazil, BVDV, diarrhea viral bovine, variability, monoclonal antibodies, cattle.

RESUMO.- [Identificação e caracterização de pestivírus isolados de amostras individuais de soro fetal bovino originárias do Rio Grande do Sul, Brasil.] A identificação da diversidade de pestivírus bovinos que circulam no campo é fundamental para a avaliação contínua dos testes de diagnóstico

\footnotetext{
${ }^{1}$ Received on January 2, 2020.

Accepted for publication on January 17, 2020

${ }^{2}$ Graduate Program in Animal Science, Universidade Federal do Pampa (Unipampa), Campus Uruguaiana, BR-472 Km 585, Uruguaiana, RS 97501-970, Brazil.

${ }^{3}$ Laboratório de Virologia e Imunologia, Faculdade de Veterinária, Universidade Federal de Pelotas (UFPel), Campus Capão do Leão, Capão do Leão, RS 96160-000, Brazil.

${ }^{4}$ Setor de Virologia, Departamento de Medicina Veterinária Preventiva, Centro de Ciências Rurais, Universidade Federal de Santa Maria (UFSM), Av. Roraima 1000, Cidade Universitária, Camobi, Santa Maria, RS 97105-900, Brazil.

${ }^{5}$ Profesor, Graduate Program in Animal Science, Laboratório de Virologia, Curso de Medicina Veterinária, Universidade Federal do Pampa (Unipampa), Campus Uruguaiana, BR-472 Km 585, Uruguaiana, RS 97501-970, Brazil. *Corresponding author: mariobrum@unipampa.edu.br
}

e composição de vacina. Neste artigo, realizamos a caracterização genética e antigênica de doze pestivírus bovinos isolados na região oeste do Rio Grande do Sul, Brasil. Os vírus foram isolados de soros de fetos bovinos ou de animais com apresentações clínicas sugestivas de infecção por pestivírus. A caracterização genética por sequenciamento e análise filogenética da região 5'UTR do genoma viral permitiu a identificação do vírus da diarréia viral bovina (BVDV-1a, 4/12, 33,3\%), BVDV-1b (6/12, $50 \%)$ e BVDV-2 (2/12, 16,7\%). A reatividade dos isolados com um painel de anticorpos monoclonais criados contra proteínas do envelope (Erns, E1 e E2) demonstrou uma alta variabilidade antigênica entre os isolados. Assim, confirmou-se a circulação ativa da infecção por pestivírus bovino, com alta variabilidade genética e antigênica, em bovinos na fronteira oeste do RS, demonstrando a importância da contínua caracterização dos pestivírus circulantes em bovinos para manter atualizadas as medidas de diagnóstico e controle.

TERMOS DE INDEXAÇÃO: Pestivírus, soro, feto, bovinos, Brasil, BVDV, pestivírus, diarreia viral bovina, variabilidade, anticorpos monoclonais. 


\section{INTRODUCTION}

Bovine pestiviruses are associated with respiratory, digestive, hemorrhagic and reproductive infection and disease (Baker 1995). The infection has a worldwide distribution and is responsible for important economic losses and, therefore, is a major target of control programs (Houe 2003, Ridpath 2003). In Brazil, its presence was first described in the late 1960s and since then it has been systematically identified in several clinical and epidemiological presentations (Botton et al. 1998, Canal et al. 1998, Silveira et al. 2015, Flores et al. 2018).

Pestivirus of cattle comprise three viral species: bovine viral diarrhea virus 1 and 2 (BVDV-1 and -2) and the HoBilike pestivirus (HoBiPeV). These viruses belong to the genus Pestivirus of the Flaviviridae family. BVDV-1, BVDV-2 and HoBiPeV were classified as Pestivirus $A, B$ and $H$, respectively (Simmonds et al. 2017, Smith et al. 2017). These viruses are enveloped and have a positive polarity single-stranded RNA genome, $12.3 \mathrm{~kb}$ in length, with a single open reading frame (ORF) containing two untranslated regions at the 5'- and 3'ends ( 5 ' and 3'UTR, respectively) (Schweizer \& Peterhans 2014). The $5^{\prime}$ UTR region is highly conserved, and in association with $\mathrm{N}^{\text {pro }}$ and E2 regions, is used for phylogenetic analysis and classification of isolates into species and subgenotypes (Ridpath et al. 1994, Silveira et al. 2015). The BVDV-1 genotype is divided into 21 subgenotypes (BVDV-1a-u), BVDV-2 in four (BVDV-2a-d) and there are indicatives of at least four $\mathrm{HoBiPeV}$ subgenotypes (HoBiPev-3a-d) (Giangaspero et al. 2008, Dias et al. 2017, Yeșilbağ et al. 2017).

Glycoproteins Erns, E1 and E2 are present in the viral envelope and they are very variable (Schweizer \& Peterhans 2014). The consequence of the genetic and antigenic variability, associated with the possibility of the emergence of new species and variants, creates the need for permanent monitoring of pestiviruses circulating in the field, as well as to update diagnostic techniques and vaccine composition (Ridpath 2003, Bauermann et al. 2013, Monteiro et al. 2018).

Several studies show that virus infection is widespread in the Brazilian cattle and seroprevalence levels varies according to the region of the country (Almeida et al. 2013, Monteiro et al. 2019). Bovine pestiviruses has already been isolated from animals with subclinical infection, herd with reproductive problems, abortions, animals with respiratory, digestive, hemorrhagic signs, mucosal disease (MD), persistently infected (PI) calves and fetal bovine serum (FBS) (Silveira et al. 2015, Flores et al. 2018). Phylogenetic analyses of isolates demonstrated that the three species are present and suggest a predominance of BVDV-1 (54.4\%), followed by BVDV-2 (25.7\%) and Hobi-like pestivirus (19.9\%) samples (Flores et al. 2018). However, the comparison of bovine herd size and number of isolates indicates deficiency in laboratory diagnosis and the need to improve isolation and characterization of samples present in the field.

Fetal infection of pregnant cows is extremely important as it can produce gestational losses (embryonic loss, abortion, malformation, mummification, teratogeny, delivery a weak calf or birth of persistently infected animals (PI). PI calves usually have no apparent clinical signs, excrete the agent indefinitely, and serve as a major source of infection for other susceptible animals (Baker 1995). Fetal bovine serum (FBS) is a supplement for cell culture and used in production of veterinary and human vaccines. Commercial FBS is a pool of several fetuses collected from slaughterhouses and bovine pestiviruses were identified as contaminating (Xia et al. 2011, Monteiro et al. 2018). Brazil is a major producer and exporter of FBS and pestivirus contamination is a constant concern for industry and laboratories (Schirrmeier et al. 2004, Bauermann et al. 2013, Monteiro et al. 2018).

Thus, this study characterized genetically and antigenically twelve pestiviruses of cattle isolated in the western region of Rio Grande do Sul, Brazil, in order to investigate their genetic and antigenic variability.

\section{MATERIALS AND METHODS}

Cells and viruses. Procedures for amplification of pestivirus of bovine and reference viruses (BVDV-1 Singer, BVDV-2 VS-253, HoBiPeV - SV757/15) were carried out on pestivirus-free bovine kidney cells (MDBK - Madin-Darby bovine kidney). The cells were cultured in minimal essential medium (Dulbecco Minimum Essential Medium) (DMEM) supplemented with $10 \%$ equine serum, antibiotic (gentamicin 50 $\mu \mathrm{g} / \mathrm{mL}$ ), antifungal (amphotericin B $1 \mu \mathrm{g} / \mathrm{mL}$ ) and maintained in at incubator with $5 \% \mathrm{CO}_{2}$ at $37^{\circ} \mathrm{C}$.

Pestivirus of bovine samples. Twelve non-cytopathogenic bovine pestiviruses belonging to the stock of the Unipampa virology laboratory were used in this study. Ten viruses were isolated from 754 serum of fetuses samples collected from 2011 to 2013 in slaughterhouses in western Rio Grande do Sul, Brazil. Samples LV14/15 and LV84/11 were isolated from the blood of a calf with retarded growth and an animal with chronic weight loss, respectively. For viral isolation, 200 microliters of sample (fetal serum or blood) were individually inoculated for 60 minutes in 24-well plates with MDBK monolayer (Botton et al. 1998). After this, three blind passages were performed at 72 hours intervals. At the end of the third passage, the supernatant was stored and the cells subjected to indirect immunofluorescence assay (IFA) with a pool of monoclonal antibodies as a primary antibody. The primary antibodies demonstrated broad reactivity and ability to recognize the three different bovine pestiviruses (Kreutz et al. 2000, Flores et al. 2018). Positive samples were identified, storage and further cultured for analyses. All isolated viruses were originated from Uruguaiana, Itaqui, Barra do Quaraí, Alegrete, Itacurubi and Maçambará municipalities.

RNA extraction and RT-PCR. MDBK cells cultures were individually infected with the isolates in 24-well polyethylene plates. After 72 hours, the supernatants were collected and subjected to RNA extraction using TRIzol ${ }^{\circledR}$ Reagent (Life Technologies, Carlsbad/CA) according to the manufacturer's instructions. The cDNA synthesis was performed with the GoScript ${ }^{\mathrm{TM}}$ Reverse Transcription Random Primers kit (Promega, Madison/WI, USA) and used as a template for the amplification of the 5'UTR region by the polymerase chain reaction (PCR). For PCR, the set of primers HCV90-368 (ForwCATGCCCATAGTAGGAC and Rev-CCATGTGCCATGTACAG) was used (RIDPATH; BOLIN; DUBOVI, 1994). The amplification conditions were: $94^{\circ} \mathrm{C}$ for $5 \mathrm{~min}$, followed by 35 cycles of 94,50 and $72^{\circ} \mathrm{C}$ for $30 \mathrm{~s}$ each, and final extension at $72^{\circ} \mathrm{C}$ for $7 \mathrm{~min}$.

Sequencing and phylogenetic analysis. The PCR products were purified with the QIAquick PCR Purification Kit (QIAGEN, Hilden, Germany) and submitted to sequencing (ACTGene Análises Moleculares Ltda, Alvorada/RS, Brazil). Consensus sequence were obtained by evaluation of forward and reverse reading of each isolate and edited using the BioEdit Sequence Alignment Editor software 
suite, version $7 \cdot 0.5 .3^{6}$ (Hall 1999). These were submitted to the Basic Local Alignment Search Tool (BLAST) ${ }^{7}$ for comparison with sequences available in GenBank and classification of the isolates for the three bovine pestivirus genotypes. Alignment of the 12 consensus sequences and 35 standard sequences was performed using the Clustal W (Thompson et al. 1997) software contained in BioEdit. Evolutionary analysis and phylogenetic reconstruction of the isolates and standard strains was performed using the Molecular

${ }^{6}$ Available at <http://www.mbio.ncsu.edu/bioedit/bioedit.html>

${ }^{7}$ Available at <http://www.ncbi.nlm.nih.gov/BLAST/>
Evolutionary Genetics Analysis (MEGA) version X (Tamura et al. 2011). The evolutionary history was inferred using the Neighbor-Joining method, and the evolutionary distances were computed using the Kimura 2-parameter method, with bootstrap values were calculated using 1000 replicates. Accession numbers of the reference sequences used in phylogenetic construction are in Fig.1.

Reactivity with a panel of monoclonal antibodies. The antigenic variability of the isolates was determined by the reactivity with 13 monoclonal antibodies (MAbs) directed to the glycoproteins Erns, E1 and E2 (Corapi et al. 1990, Kreutz et al. 2000). For this, MDBK cells infected with each isolate were trypsinized, resuspended and deposited on multispot slides, and after cell adhesion, cells

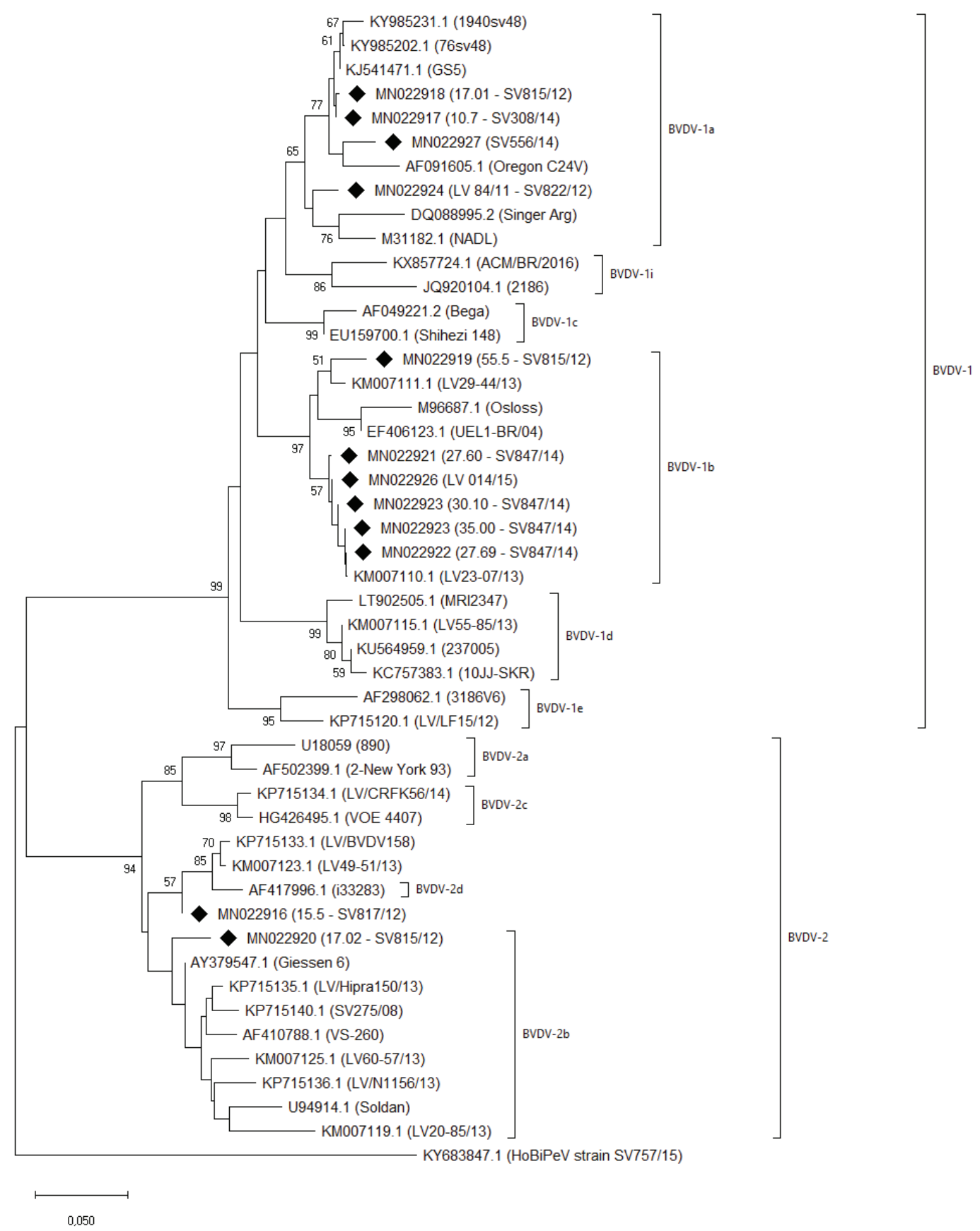

Fig.1. Phylogenetic analysis constructed by the Neighbor-Joining method, Kimura-2 parameter, based on the 5'UTR region of 12 nucleotide sequences of bovine pestivirus isolates ( $\$ 411$ positions). Only bootstrap values (1000 replicates) above 50\% are demonstrated. 
were fixed with cold acetone. The ability of each MAb to recognize antigens of the isolates was investigated by the IFA technique (indirect immunofluorescence) (Botton et al. 1998). MAbs were used individually as primary antibody and an anti-mouse fluoresceinconjugated anti-IgG (Sigma-Aldrich, St. Louis/MO, USA) was used as secondary antibody. As a positive and negative control, standard strains (BVDV-1 Singer, BVDV-2 VS-253 and HoBiPeV SV757/15) and uninfected cells were used, respectively.

\section{RESULTS}

Individual analysis of $754 \mathrm{FBS}$ allowed the isolation of 10 viruses, thus $1.3 \%$ of the samples tested were actively infected with bovine pestivirus. Two other samples from suspected cases were also included in the study. These viruses isolates provide an overview of the circulating samples in the region studied. All isolated samples were classified as non-cytopathic (NCP).

The genetic and antigenic characterization demonstrated that the twelve pestivirus isolates belong to BVDV-1 and -2 species and display a broad antigenic variability (Fig.1 and Table 1). Phylogenetic analysis identified ten samples as BVDV-1 (83.3\%) and two viruses as BVDV-2 (16.7\%). Among viruses classified as BVDV-1, four belong to the BVDV-1a genotype $(4 / 12,33.3 \%)$ and six are BVDV-1b $(6 / 12,50 \%)$. Among samples compatible with BVDV-2, isolate 17.02 was grouped as BVDV-2b, whereas 15.5 could not be classified in either BVDV-2 subgenotype (Fig.1).

The reactivity of the MAbs with the isolates confirmed a wide antigenic variability among the BVDVs (Table 1). No MAb used recognized $100 \%$ of the isolates. The level of recognition of the isolates by MAbs varied between 30.7 and $84.6 \%$, reaffirming the wide variability among the isolates. The variability could be observed between the isolates and the standard strains, as well as among the different genotypes.

\section{DISCUSSION}

Pestivirus isolates from fetal serum and from animals with clinical signs were classified as BVDV-1 and BVDV-2 and confirmed the existence of genetic and antigenic variability among isolates. Among the analyzed samples, the presence of BVDV-1 (10/12) was predominant in relation to BVDV-2 $(2 / 12)$. Despite of the limited number of viruses characterized, these findings are consistent with previous studies that characterized a more comprehensive sampling and demonstrate a predominance of BVDV-1 in Brazilian cattle herds (Weber et al. 2014, Silveira et al. 2015, Flores et al. 2018). The BVDV$1 \mathrm{a}(4 / 10)$ and BVDV-1b (6/10) subgenotypes were the two identified in the present study and reflect what has already been demonstrated in other regions of the country (Silveira et al. 2015, Flores et al. 2018). The representative circulation of bovine pestivirus genotypes in a given region can be determined when at least 50 virus samples are analyzed (Flores et al. 2018). Thus, the small number of samples studied herein can not be considered representative of the western region of Rio Grande do Sul, but they suggest the predominance of these two genotypes and demonstrate the circulation of these viruses in the cattle population.

In the present study, it was possible to determine that isolate 15.5 (SV817/12) belongs to the BVDV-2 species, without classification in subgenotype. The difficulty in determining the subgenotype also occurred with isolates of the BVDV-2 in other studies (Weber et al. 2014, Silveira et al. 2015, Monteiro et al. 2018). The analysis of the 5'UTR region alone may not be sufficient to determine the subgenotype for some viruses. In these situations, it is suggested to sequence the $\mathrm{N}^{\text {pro }}$ and E2 regions to obtain the definitive virus genotype classification (Pellerin et al. 1994, Ridpath et al. 1994, Silveira et al. 2015, Monteiro et al. 2018). No HoBiPeV isolates were identified in the present study. HoBiPeV are recognized as a new emerging bovine pestivirus species and represent the smallest group $(<20 \%)$ among the three pestivirus species identified in Brazil (Silveira et al. 2015, Flores et al. 2018).

The evaluation of the envelope glycoproteins profile performed with MAbs confirmed the antigenic variability among the isolates. Erns, E1 and, especially E2 glycoproteins are responsible for the interactions of the virus with the cellular

Table 1. Reactivity of a panel of monoclonal antibodies (mAb) with bovine pestiviruses from western of Rio Grande do Sul State, Brazil

\begin{tabular}{|c|c|c|c|c|c|c|c|c|c|c|c|c|c|}
\hline \multirow{2}{*}{ Isolates } & \multicolumn{13}{|c|}{ Reactivity of monoclonal antibodies } \\
\hline & $\begin{array}{c}\text { E0 } \\
3 . D .8 \\
\end{array}$ & $\begin{array}{c}\text { E1 } \\
\text { 6.F.11 }\end{array}$ & 19.F.9 & F.11.4.8 & 20.G.7 & 31.C. 4 & 18.D.4 & 7.1.8 & 6.D.11 & 10.F.9 & 32.B.3 & 2.D.5 & 6.C.5 \\
\hline 10.7 (SV308/14) & + & - & + & - & + & - & + & + & - & + & - & + & - \\
\hline SV 556/14 & - & + & - & - & + & + & - & + & + & - & - & - & + \\
\hline 55.5 (SV815/12) & + & + & + & + & + & + & - & + & + & + & - & + & + \\
\hline 27.60 (SV847/14) & - & + & + & - & - & - & + & + & + & + & - & - & - \\
\hline LV 014/15 & + & + & + & - & - & - & + & - & + & - & - & + & - \\
\hline 30.10 (SV847/14) & + & - & + & - & - & + & + & + & + & + & - & + & - \\
\hline 35.00 (SV847/14) & + & + & + & - & - & + & + & + & + & - & - & + & - \\
\hline
\end{tabular}


receptors, and are associated with virulence and induction of the neutralizing antibodies (Schweizer \& Peterhans 2014). The variability observed in these proteins reflects on the serological reactivity between different viral samples, being possible vaccine failures (Ridpath 2003, Otonel et al. 2014). Therefore, constant monitoring of the viruses circulating in the field, associated with the update of the vaccine strains, are some of the alternatives necessary to guarantee the control programs and vaccine efficacy (Ridpath 2003).

The use of a single monoclonal antibody in tests for identification and/or diagnosis of pestiviruses of bovine is not advisable since it may lead to false-negative results. For these cases, it is recommend to use a pool of monoclonal antibodies or specific antibodies for the conserved regions, such as the NS2/3 nonstructural protein, or polyclonal antibodies (Botton et al. 1998, Bauermann et al. 2013). Still, the genetic diversity also has consequences in the diagnosis by PCR. For this situation, it is recommend to use a set of primers with the capacity to detect the largest number of variants in small concentrations of genetic material (Giangaspero \& Harasawa 2011, Monteiro et al. 2018).

The presence of more than one viral species infecting the same herd is a well-recognized possibility (Otonel et al. 2014). The explanation for this phenomenon is the constant mutations and recombination characteristic of pestiviruses or by the introduction into the herd of animals carrying different genotypes (Ridpath 2003, Fulton 2015). Genetic diversity is accompanied by the antigenic variability of the samples. In practical terms, genetic and antigenic diversity contribute to vaccine failures, when cross-serology among samples of distinct genotypes is not efficient (Fulton 2015). This situation reinforces that programs for the control and prevention of bovine pestivirus infection should follow the principle of identification and removal of persistently infected (PI) animals and using effective vaccines.

Isolation of bovine pestiviruses in FBS samples has been performed with some frequency. In previous study, that tested individual fetal serum the prevalence $(0.7 \%)$ was similar (Botton et al. 1998). Monitoring of commercial batches of FBS has identified genome or virus infective, but without precision in determining the origin of infected herds (Xia et al. 2011, Monteiro et al. 2018). Despite the difficulty in obtaining, testing of individual FBS can be considered an excellent source of bovine pestiviruses, as it demonstrates active infection of pregnant animals and provides an overview of virus diversity circulating (Botton et al. 1998, Flores et al. 2018, Monteiro et al. 2018). The presence of fetal infection the virus infecting the fetus may also be associated with failure of fetal protection and consequent maintenance of the epidemiological cycle in herds. A cornerstone of any bovine pestiviruses control program is to prevent infection of pregnant cows (Ridpath 2003). In this way, monitoring of fetal samples may be helpful in evaluating the control program in certain regions. Diagnostic tests capable of detecting fetal infection of pregnant cows would be a major advance in disease control (Houe 2003, Ridpath 2003).

Economic losses produced by bovine pestiviruses are related to productive and, especially to reproductive failure (Houe 2003). In the present study, around 1.3\% (10/754) of the fetal serum samples analyzed contained infectious virus. Although the consequences of these infections could not be determined, transplacentary BVDV infection may result in several outcomes, including fetal malformation, abortion or the birth of infected persistent animals. Another important aspect associated with fetal infection is the use of contaminated fetal bovine serum in the biological industry, including vaccines.

\section{CONCLUSIONS}

Pestiviruses circulate actively in cattle in the western region of the State of Rio Grande do Sul, Brazil. There are both genetic and antigenic variability among the pestiviruses isolated, being possible to detect the two major species of bovine pestiviruses, BVDV-1 and BVDV- 2 .

The numbers of samples evaluated is small, but corroborate with other studies that analyzed a larger number of samples of viruses.

Taken together, the results reinforce the need to continuous monitoring of the genetic and antigenic properties of circulating field samples.

Acknowledgements.- Scholarship was received from the "Coordenação de Aperfeiçoamento de Pessoal de Nível Superior" (CAPES), Brazil (IM and FLM). This study was financed in part by "Fundação de Apoio a Pesquisa do Rio Grande do Sul" (FAPERGS ARD 10/0222-0) , by CAPES (Financial code 001), and "Pró-Reitoria de Pesquisa, Pós-Graduação e Inovação", "Universidade Federal do Pampa” (PROPPI/Unipampa). The authors thank Frigoeste and Callegaro slaughterhouses for serum of fetus's collection.

Conflict of interest statement.- The authors declare that they have no conflict of interest.

\section{REFERENCES}

Almeida L.L., Miranda I.C., Hein H.E., Neto W.S., Costa E.F., Marks F.S., Rodenbusch C.R., Canal C.W. \& Corbellini L.G. 2013. Herd-level risk factors for bovine viral diarrhea virus infection in dairy herds from Southern Brazil. Res. Vet. Sci. 95(3):901-917. <http://dx.doi.org/10.1016/j.rvsc.2013.08.009> <PMid:24079841>

Baker J.C. 1995. The clinical manifestations of bovine viral diarrhea infection. Vet. Clin. N. Am., Food Anim. Pract. 11(3):425-445. <http://dx.doi. org/10.1016/S0749-0720(15)30460-6><PMid:8581856>

Bauermann F.V., Ridpath J.F., Weiblen R. \& Flores E.F. 2013. HoBi-like viruses: an emerging group of pestiviruses. J. Vet. Diagn. Invest. 25(1):6-15. <http:// dx.doi.org/10.1177/1040638712473103><PMid:23345268>

Botton A.S., Silva A.M., Brum M.C.S., Weiblen R. \& Flores E.F. 1998. Antigenic characterization of Brazilian bovine viral diarrhea virus isolates by monoclonal antibodies and cross-neutralization. Braz. J. Med. Biol. Res. 31(11):14291438. <http://dx.doi.org/10.1590/S0100-879X1998001100011>

Canal C.W., Strasser M., Hertig C., Masuda A. \& Peterhans E. 1998. Detection of antibodies to bovine viral diarrhoea virus (BVDV) and characterization of genomes of BVDV from Brazil. Vet. Microbiol. 63(2/4):85-97. <http:// dx.doi.org/10.1016/S0378-1135(98)00232-6><PMid:9850989>

Corapi W.V., Donis R.O. \& Dubovi E.J. 1990. Characterization of a panel of monoclonal antibodies and their use in the study of the antigenic diversity of bovine viral diarrhea virus. Am. J. Vet. Res. 51(9):1388-1394. <PMid:2168687>

Dias R.K., Cargnelutti J.F., Weber C.W., Bauermann F.V., Ridpath J.F., Weiblen R. \& Flores E.F. 2017. Antigenic diversity of Brazilian isolates of HoBi-like pestiviruses. Vet. Microbiol. 203:221-228.<http://dx.doi.org/10.1016/j. vetmic.2017.03.021><PMid:28619148>

Flores E.F., Cargnelutti J.F., Monteiro F.L., Bauermann F.V., Ridpath J.F. \& Weiblen R. 2018. A genetic profile of bovine pestiviruses circulating in Brazil (1998- 
2018). Anim. Health Res. Rev. 19(2):134-141.<http://dx.doi.org/10.1017/ S1466252318000130><PMid:30683172>

Fulton R.W. 2015. Impact of species and subgenotypes of bovine viral diarrhea virus on control by vaccination. Anim. Health Res. Rev. 16(1):40-54. <http://dx.doi.org/10.1017/S1466252315000079><PMid:26050571>

Giangaspero M. \& Harasawa R. 2011. Species characterization in the genus Pestivirus according to palindromic nucleotide substitutions in the 5'-untranslated region. J. Virol. Methods 174(1/2):166-172. <http://dx.doi.org/10.1016/j.jviromet.2011.04.004><PMid:21514324>

Giangaspero M., Harasawa R., Weber L. \& Belloi A. 2008. Genoepidemiological evaluation of bovine viral diarrhea virus 2 species based on secondary structures in the 5' untranslated region. J. Vet. Med. Sci. 70(6):571-580. <http://dx.doi.org/10.1292/jvms.70.571><PMid:18628597>

Hall T.A. 1999. BioEdit: a user-friendly biological sequence alignment editor and analysis program for Windows 95/98/NT. Nucleic Acids Symp. Ser. 41:95-98. <http://dx.doi.org/10.14601/Phytopathol_Mediterr-14998u1.29>

Houe H. 2003. Economic impact of BVDV infection in dairies. Biologicals 31(2):137-143. <http://dx.doi.org/10.1016/S1045-1056(03)00030-7> $<$ PMid:12770546>

Kreutz L.C., Donis R., Gil L.H.V., Lima M., Hoffman A.N., Garcez D.C., Flores E.F. \& Weiblen R. 2000. Production and characterization of monoclonal antibodies to Brazilian isolates of bovine viral diarrhea virus. Braz. J. Med. Biol. Res. 33(12):1459-1466. <http://dx.doi.org/10.1590/S0100879X2000001200010>

Monteiro F.L., Cargnelutti J.F., Brauinig P., Folgueras-Flatschart A.V., Santos N.C., Pituco E.M., Weiblen R. \& Flores E.F. 2018. Detection and genetic identification of pestiviruses in Brazilian lots of fetal bovine serum collected from 2006 to 2014. Pesq. Vet. Bras. 38(3):387-392. <http://dx.doi.org/10.1590/1678-5150-pvb-5283>

Monteiro F.L., Martins B., Cargnelutti J.F., Noll J.G., Weiblen R. \& Flores E.F. 2019. Genetic identification of pestiviruses from beef cattle in Southern Brazil. Braz. J. Microbiol. 50(2):557-563. <http://dx.doi.org/10.1007/ s42770-019-00058-6><PMid:30877664>

Otonel R.A., Alfieri A.F., Dezen S., Lunardi M., Headley A.S. \& Alfieri A.A. 2014. The diversity of BVDV subgenotypes in a vaccinated dairy cattle herd in Brazil. Trop. Anim. Health Prod. 46(1):87-92.<http://dx.doi.org/10.1007/ s11250-013-0451-y><PMid:23877647>

Pellerin C., Van den Hurk J., Lecomte J. \& Tijssen P. 1994. Identification of a new group of bovine viral diarrhea virus strains associated with severe outbreaks and high mortalities. Virology 203(2):260-268. <http://dx.doi.org/10.1006/viro.1994.1483><PMid:8053150>

Ridpath J.F. 2003. BVDV genotypes and biotypes: practical implications for diagnosis and control. Biologicals 31(2):127-131. <http://dx.doi.org/10.1016/S1045-1056(03)00028-9><PMid:12770544>
Ridpath J.F., Bolin S.R. \& Dubovi E.J. 1994. Segregation of bovine viral diarrhea virus into genotypes. Virology 205(1):66-74. <http://dx.doi.org/10.1006/ viro.1994.1620 > <PMid:7975238>

Schirrmeier H., Strebelow G., Depner K., Hoffmann B. \& Beer M. 2004. Genetic and antigenic characterization of an atypical pestivirus isolate, a putative member of a novel pestivirus species. J. Gen. Virol. 85(Pt 12):3647-3652. <http://dx.doi.org/10.1099/vir.0.80238-0> <PMid:15557237>

Schweizer M. \& Peterhans E. 2014. Pestiviruses. Ann. Rev. Anim. Biosci. 2(1):141-163. <http://dx.doi.org/10.1146/annurev-animal-022513-114209>

Silveira S., Weber M.N., Mósena A.C., Silva M.S., Streck A.F., Pescador C.A., Flores E.F., Weiblen R., Driemeier D., Ridpath J.F. \& Canal C.W. 2015. Genetic diversity of brazilian bovine pestiviruses detected between 1995 and 2014. Transbound. Emerg. Dis. 64(2):613-623. <http://dx.doi.org/10.1111/ tbed.12427 $><$ PMid:26415862 $>$

Simmonds P., Becher P., Bukh J., Gould E.A., Meyers G., Monath T., Muerhoff S., Pletnev A., Rico-Hesse R., Smith D.B. \& Stapleton J.T. 2017. ICTV virus taxonomy profile: Flaviviridae. J. Gen. Virol. 98(1):2-3. <http://dx.doi.org/10.1099/ jgv.0.000672><PMid:28218572>

Smith D.B., Meyers G., Bukh J., Gould E.A., Monath T., Muerhoff A.S., Pletnev A., Rico-Hesse R., Stapleton J., Simmonds P. \& Becher P. 2017. Proposed revision to the taxonomy of the genus Pestivirus, family Flaviviridae. J. Gen.Virol. 98(8):2106-2112. <http://dx.doi.org/10.1099/jgv.0.000873> $<$ PMid:28786787>

Tamura K., Peterson D., Peterson N., Stecher G., Nei M. \& Kumar S. 2011. MEGA5: molecular evolutionary genetics analysis using maximum likelihood, evolutionary distance, and maximum parsimony methods. Mol. Biol. Evol. 28(10):2731-2739.<http://dx.doi.org/10.1093/molbev/ msr121><PMid:21546353>

Thompson J.D., Gibson T.J., Plewniak F., Jeanmougin F. \& Higgins D.G. 1997. The CLUSTAL_X windows interface: flexible strategies for multiple sequence alignment aided by quality analysis tools. Nucleic Acids Res. 25(24):48764882. <http://dx.doi.org/10.1093/nar/25.24.4876><PMid:9396791>

Weber M.N., Silveira S., Machado G., Groff F.H., Mósena A.C., Budaszewski R.F., Dupont PM., Corbellini L.G. \& Canal C.W. 2014. High frequency of bovine viral diarrhea virus type 2 in Southern Brazil. Virus Res. 191:117-124 <http://dx.doi.org/10.1016/j.virusres.2014.07.035><PMid:25109547>

Xia H., Vijayaraghavan B., Belák S. \& Liu L. 2011. Detection and identification of the atypical bovine pestiviruses in commercial foetal bovine serum batches. PLoS One 6(1):e28553. <http://dx.doi.org/10.1371/journal. pone.0028553><PMid:22174836>

Yeşilbağ K., Alpay G. \& Becher P. 2017. Variability and global distribution of subgenotypes of bovine viral diarrhea virus. Viruses 9(6):128. <http://dx.doi.org/10.3390/v9060128><PMid:28587150> 